\title{
Retention of Active Ingredients in Solar Drying
}

\author{
M.R. Parmar*, V.B. Bhalodiya and R.L. Rajput \\ College of Horticulture, Anand Agricultural University, Anand, India \\ *Corresponding author
}

\section{A B S T R A C T}

\begin{tabular}{|l|}
\hline Ke y w o r d s \\
Aroma, Drying treatment, \\
Basil leaves, Solar drying, \\
Active ingredient
\end{tabular}

10 October 2018

\begin{abstract}
The proper drying techniques are the most important aspect for preservation of aroma and colour of basil leaves. The use of solar dryer helps to reduce the moisture content and improves the quality product. Drying treatment and experimental method for solar drying was carried out at the temperatures of $45^{\circ} \mathrm{C}, 55^{\circ} \mathrm{C}$ and $65^{\circ} \mathrm{C}$ to find and suggest the optimum drying condition for acquiring quality dried basil leaves and active ingredient like uginol, caryophyll of basil leaves. Results have revealed that 'total drying time' is considerably reduced with the increase in drying air temperatures from $45^{\circ} \mathrm{C}$ to $65^{\circ} \mathrm{C}$. It could be recommended that for the best drying temperature is $45^{\circ} \mathrm{C}$ of basil leaves to retain the various active ingredient.
\end{abstract}

\section{Introduction}

The major focus for drying basil leaves often remained centered around a point where its aroma needs to be preserved beside the appearance and nutritional characteristics. Researchers (Diaz-Maroto et al., 2002; Brophy et al., 1986; Fleisher, 1981) have reported that improper drying may cause losses in volatilities or formation of new volatilities as a result of oxidation and esterification reactions.

The volatile composition of basil is found to be dependent on the variety and/or geographical cultivation of the basil plant depending upon main components (Linalool, methyl cinnamate, eugenol, methyl eugenol, and etc.) of this precious herb. The majority of findings have revealed this fact where the drying is reported to influence changes in the volatile compounds present in basil.

If we look from quantitative points of view, these decreases in the total amounts of essential oils have been reported to varied tune, say being $36 \%$ to $45 \%$ for sweet basil during drying at ambient temperature (Nykanen and Nykanen, 1987; 1989). A study by Yousif et al., (1999) showed significant difference in concentrations of linalool and methyl chavicol in air-dried basil samples compared to those present in fresh samples, while that of vacuum dried samples showed substantial increase of about 2.5 fold for linalool and 1.5 fold for methyl chavicol, compared to that present in air-dried samples. Di Cesare et al., (1994; 2000; 2001; 2002; 2003) found microwave drying to retain high percentages of characteristic volatile 
compounds (eucalyptol, linalool, eugenol, and methyl eugenol) in basil (Ocimum basilicum L.) compared to samples dried by air-drying and freeze-drying with blanching, except freeze-dried unblanched leaves. Other studies on drying methods on volatilities of leaf (Diaz-Maroto et al., 2002), and spearmint (Diaz-Maroto et al., 2003) too have given such logical variability.

Yuparat et al., (2014) utilized some of the predictive models to evaluate the performances as well as influences of certain parameters towards drying of leaves and other similar materials by fitting prevailing moisture versus time data to five different crop drying models. The drying constants were well related to the drying temperatures. The ultimate findings of Abdollah et al., (2014) reflected the facts that (1) drying temperatures can decrease essential oil contents of basil, (2) drying methods can change the chemical profile of essential oil of basil, and (3) oven drying at $40^{\circ} \mathrm{C}$ had the least effect on essential oil.

Looking into plethora of such studies and their findings towards temperature effects on drying and volatile components of basil leaf, present research was conceived and conducted in India whose preliminary results are reported herein. The major aim of the work was to examine the influence of various drying methods and retention of phytochemical on a couple of crop varieties as cultivated in India, leaves cultivated in this specific region of India, to promote its market/utility and also to maintain its nutritional value and other qualitative parameters in an optimum manner.

\section{Materials and Methods}

\section{Materials and equipments}

The variety of basil grown for the experiment was the green basil. In the green basil, varieties were kept same as far as possible. The plant leaves were manually nibbed from the basil plant and cleaned with water spray at evening so as to remove dust and other impurities. For drying of basil leaves solar dryer was used. For chemical analysis, clevenger type apparatus for volatile oil measurement and GC-MS for active ingredients determination were used.

\section{Blanching}

Steam blanching for 30 seconds before drying. was carried out.

\section{Measurement of variables}

Methods used to measure different variables are described below:

\section{Air temperature}

Air temperature was measured using mercury thermometer (capacity: $0-110{ }^{\circ} \mathrm{C}$, least count: $1{ }^{\circ} \mathrm{C}$ ) as well as digital temperature recorder (capacity: $0-200{ }^{\circ} \mathrm{C}$, least count: $0.1^{\circ} \mathrm{C}$ ). The air temperature was controlled within $\pm 0.1^{\circ} \mathrm{C}$ during the experiment by adjusting the thermostat.

\section{Air velocity}

Air velocity was determined by using the digital anemometer (Agrawal Electronics, Mumbai-Model 8903). The velocity range of anemometer was $0.1-35.0 \mathrm{~m} / \mathrm{s}$.

\section{Moisture content}

\section{Average drying rate}

Accordingly the average drying rates at different timings during the low temperature drying were computed in all experimental conditions using following relationship. 
$\frac{d M}{d t}=\frac{\left(M_{t}-M_{t+\Delta t}\right)}{\Delta t}$

Where,

$\frac{d M}{d t}=$ average drying rate, $\%$ d.b. /minute

$\mathrm{t}=$ time at any instant, minute

$\mathrm{t}+\Delta \mathrm{t}=$ time after an interval of $\Delta \mathrm{t}$, minute

Experimental procedure

\section{Cleaning}

Fresh basil leaves were taken from the plants grown in campus and thoroughly cleaned before manual nibbing. The soft stems were removed and basil leaves were separated and cleaned manually to remove soil and dust particles if any attached to it.

\section{Sample preparation}

Cleaned basil leaves were weighed in digital balance (Simanzu make, Capacity: 220 g, least count: $0.01 \mathrm{~g}$ ). Samples were prepared and placed in tray for solar drying.

\section{Pretreatment of sample}

Weighed basil leaves were pretreated by steam blanching for 30 seconds by keeping them in a sieve above the boiled hot water to receive the steam coming from it.

Steam blanched samples were placed over a perforated tray to separate the stuck leaves during steaming.

After that weight sample of leaves was loaded into perforated aluminum tray in solar dryer. Fresh sample without pretreatment was used as control

\section{Drying methods used}

The drying of basil leaves was carried out using solar dryer. Treatment was carried out with samples in triplicate.

Each $100 \mathrm{~g}$ blanched and unblanched samples were uniformly spread in the perforated aluminum tray and dried at the desired temperature.

The moisture loss was recorded by using top pan digital balance.

\section{Solar drying}

The solar drying studies of basil leaves were carried out in the commercial solar dryer available. The modular size of the solar dryer was $1000 \mathrm{~mm}$ x $2000 \mathrm{~mm}$. Total modules were two having loading capacity upto $10 \mathrm{~kg}$ per batch. The tray size and numbers were 500 $\mathrm{mm} \times 425 \mathrm{~mm} \times 25 \mathrm{~mm}$ and 8 numbers respectively. The trays were made of stainless steel with SS wire mesh. Inlet, outlet and ambient temperatures were recorded.

Each $100 \mathrm{~g}$ blanched and unblanched samples were uniformly spread in single layer on a perforated stainless steel wire mess tray and dried at the desired temperature. The moisture loss was recorded at every 60 min interval using top pan digital balance

\section{Estimation of volatile oil}

\section{Sample preparation}

For the estimation of volatile oil in the dried basil leaves, minimum $50 \mathrm{~g}$ dried sample was taken. To collect $50 \mathrm{~g}$ dried sample, at least $300 \mathrm{~g}$ fresh leaves were collected to dry in hot air tray dryer. For duplication total $600 \mathrm{~g}$.

Fresh leaves were collected and dried for volatile oil sample analysis. 


\section{Determination of volatile oil content}

The volatile oil content of basil leaves was estimated as described by the Bureau of Indian Standards (SP: 18(part Vii)-1982).

$50 \mathrm{~g}$ of basil leaves were transferred into 1 liter round bottomed flask and then water was added to fill the flask slightly less than half full and mixed by swirling. To this few glass beads were also added. The flask was connected through calibrated oil trap to the condenser. The mixture was distilled for four hours until there was no increase in the oil content over a period of 1 hour. The setup was cooled to room temperature and allowed to stand until the oil layer was clear. The volatile oil was collected in the trap, was measured in $\mathrm{ml}$.

\section{GC - MS conditions}

For the identification of the volatiles compounds, some samples were subjected to GC- MS analysis on a Perkin Elemer Autosystem Excel with Turbomass. Conditions were as follows:

Mode: TIC (Total Ion Chromatogram)

Column Type: PE- 5 (MS)

Column Oven Temperature: $70{ }^{\circ} \mathrm{C}$ (5 minute) $-80{ }^{\circ} \mathrm{C}(10$ minute $)$

Injector Temperature: $250{ }^{\circ} \mathrm{C}$

Detector: Quadrupole

Ion Source Temperature: $250{ }^{\circ} \mathrm{C}$

Carrier Gas: Helium

Flow Rate: $1 \mathrm{ml} / \mathrm{min}$

Split Ratio: 1: 5

\section{Results and Discussion}

\section{Initial moisture content}

The basil leaves were collected from the plants grown in campus. Samples of the fresh basil leaves was $81.68 \%$ (w. b.) at the time of harvest. The range of moisture content varied from $81.00-83.00 \%$ (w. b.), which shows that the basil leaves can be considered under highly perishable group.

\section{Drying characteristics of basil leaves}

The drying characteristics of basil leaves were analyzed using the experimental data on moisture of product at various time intervals for different drying conditions. After pretreatment, the samples were dried up to the safe moisture content level of 4 to $6 \%$ (\% d.b.).

Relation of time, and drying rate (\% d.b./min) was attempted to characterize the drying behaviour of basil leaves. The drying rate was compared for the blanched and unblanched samples with different time, temperature for solar dryer.

The basil leaves were steamed and thus had some moisture on the surface of basil leaves due to which blanched shows higher moisture content then actual.

\section{Average drying rate}

To analyze the effect of drying conditions on rate of drying, average drying rate was computed for each experiment.

The average drying rate represents the rate of change of moisture content (\% d.b.) over a particular time interval and is attributed to the middle of the time interval. The average rate of drying is expected to decrease continuously with the drying time, being faster at higher 
temperatures except for constant rate drying conditions.

\section{Solar drying}

In the solar drying of basil leaves at the $45{ }^{\circ} \mathrm{C}$ temperature, average drying rate decreased from 1.36 to $0.06 \% \mathrm{~d}$. b./min for the drying of unblanched basil leaves. For the blanched leaves average drying rate was reduced from 2.02 to $0.29 \%$ d.b./min in the solar drying. The arithmetic decrement in drying rate was 1.30 for the unblanched leaves at the $45{ }^{\circ} \mathrm{C}$ temperature, while it was $1.73 \%$ d.b./min for blanched sample

At $55{ }^{\circ} \mathrm{C}$ temperature, the drying rate decreased from 1.81 to $0.38 \%$ d.b./min for drying of unblanched sample, while from 2.85 to $0.72 \%$ d.b./min for drying of blanched leaves. The arithmetic decrement in drying rate for $55{ }^{\circ} \mathrm{C}$ temperature was observed as $1.43 \%$ d.b./min and $2.13 \%$ d.b./min for unblanched and blanched samples, respectively.

At $65{ }^{\circ} \mathrm{C}$ temperature, the drying rate decreased from 2.57 to $1.20 \%$ d.b./min for drying of unblanched sample while from 4.18 to $2.03 \% \mathrm{~d} . \mathrm{b} . / \mathrm{min}$ for drying of blanched leaves. The arithmetic decrement in drying rate for $65{ }^{\circ} \mathrm{C}$ temperature was observed as $1.07 \%$ d. b. /min and $2.15 \%$ d.b./min for unblanched and blanched samples, respectively.

At 45,55 and $65{ }^{\circ} \mathrm{C}$ temperature, the drying rate decreased from $1.35,1.81$ and $2.57 \%$ d.b./min to $0.06 \%, 0.38$ and $1.20 \%$ d.b./min in the drying of unblanched basil leaves while from $2.02,2.85$ and $4.18 \%$ d.b./min to 0.29 $\%, 0.72$ and $2.03 \%$ d.b./min in the drying of blanched leaves. The arithmetic decrement in drying rate in the unblanched samples at 45, 55 and $65{ }^{\circ} \mathrm{C}$ drying were observed as 1.30 , 1.43 and $1.07 \%$ d. b./min and for blanched the arithmetic decrement were 1.73, 2.13 and $2.15 \%$ d.b./min.

This showed that the drying rate was rapidly decreasing in the blanched sample than the unblanched sample at $45,55,65{ }^{\circ} \mathrm{C}$ temperature, respectively. The trend of variation of drying rate with time is shown in Figures 1, 2 and 3 for blanched and unblanched drying for 45,55 and $65{ }^{\circ} \mathrm{C}$ temperature, respectively.

\section{Effect of drying conditions on volatile oil content}

Volatile oil content of dried basil leaves is presented in Table 1. It showed that volatile oil of samples varied from 0.40 to 0.76 $\mathrm{ml} / 100 \mathrm{~g}$ d.m. In case of unblanched samples, oil content loss was less as compared to blanched sample. This might be due to the oil content loss during the blanching treatment. In solar drying of basil leaves at 45,55 and $65{ }^{\circ} \mathrm{C}$ temperatures, the volatile oil content was found as $0.76,0.0 .58$ and $0.50 \mathrm{ml} / 100 \mathrm{~g} \mathrm{d.m.,}$ respectively, in the unblanched samples. Whereas, 0.73, 0.53 and $0.40 \mathrm{ml} / 100 \mathrm{~g}$ d.m., respectively, in case of blanched samples. The volatile content of fresh sample was 1.36$\mathrm{ml} / 100 \mathrm{~g} \mathrm{d.m}$. The loss of volatile oil content was very high ranging from $63.24 \%$ (blanched,) to $70.59 \%$ (unblanched) for solar drying at $65{ }^{\circ} \mathrm{C}$. Loss of volatile oil content was higher when basil leaves were dried at higher temperature. This might be because of the breakage of oil cell due to heating, which leads to loss of volatile oil. It was also observed that although at higher temperature the drying time was shorter, the loss of volatile oil was higher.

From the Table 1 it was revealed that volatile loss was minimum $46.33 \%$ d.m. in the blanched samples at the $45{ }^{\circ} \mathrm{C}$ temperature in the solar dryer, in unblanched samples loss was minimum to $44.12 \%$. 
Fig.1 Variation in average drying rate of basil leaves with drying time for solar drying at $45{ }^{\circ} \mathrm{C}$

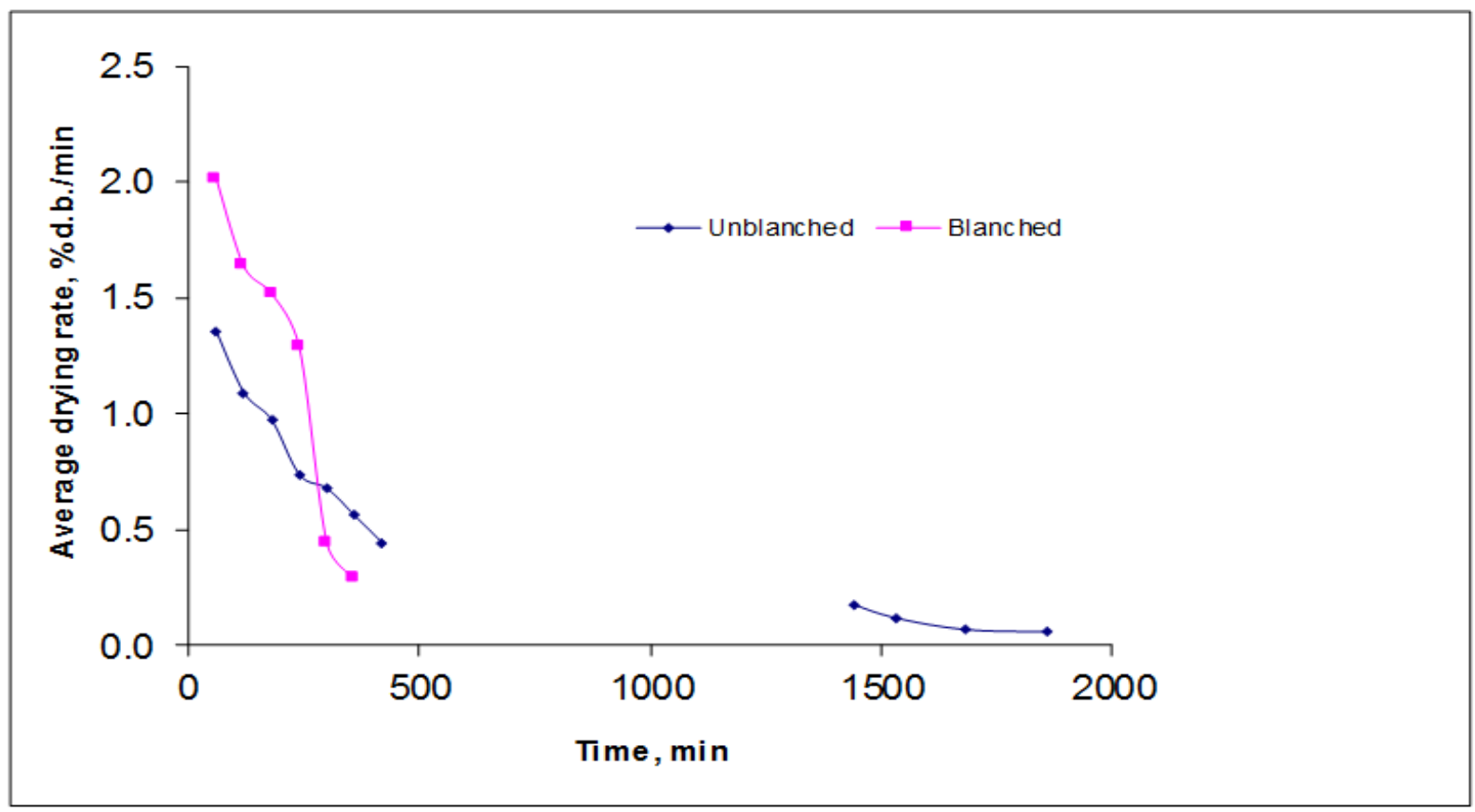

Fig.2 Variation in average drying rate of basil leaves with drying time for solar drying at $55{ }^{\circ} \mathrm{C}$

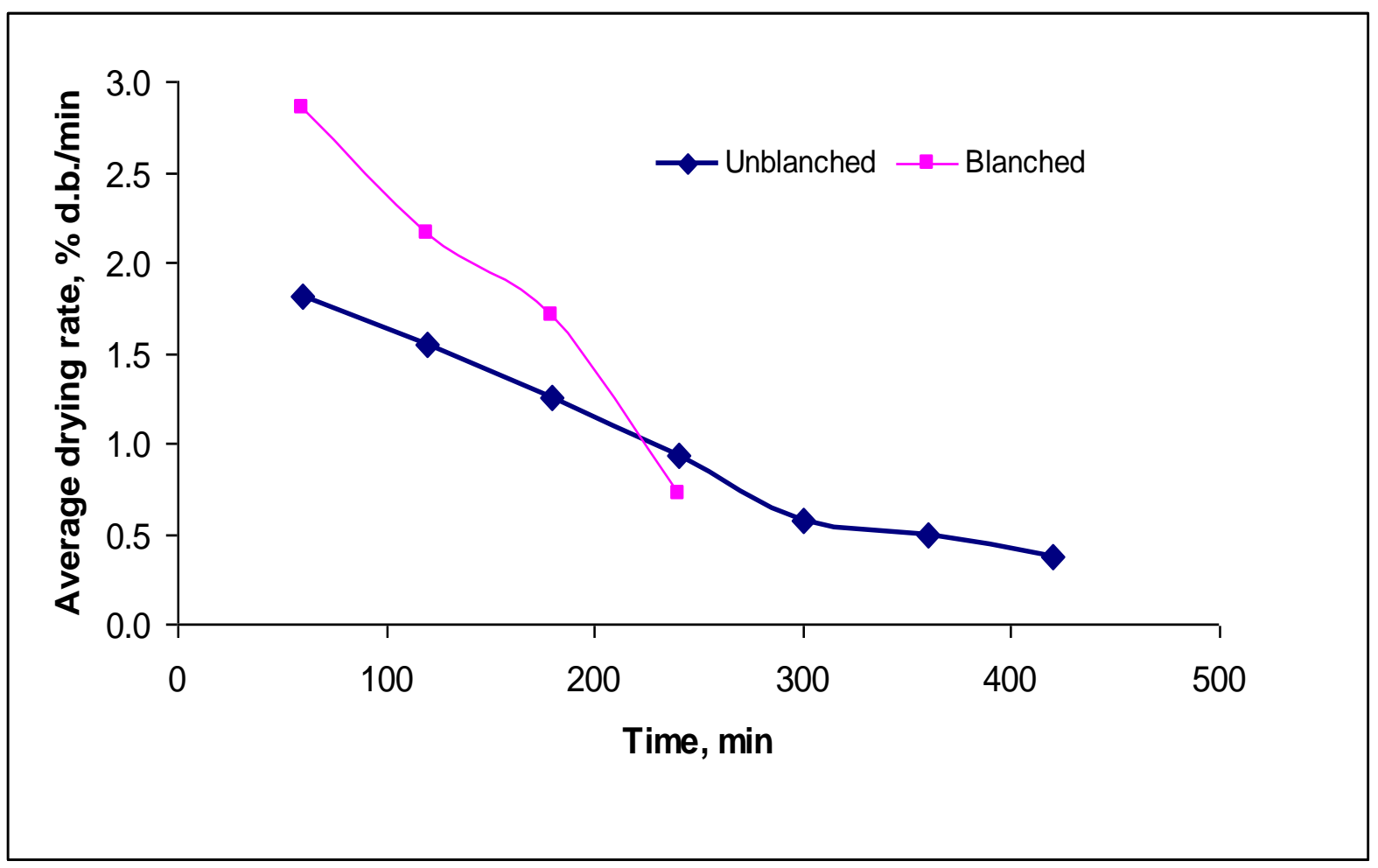


Fig.3 Variation in average drying rate of basil leaves with drying time for solar drying at $65^{\circ} \mathrm{C}$

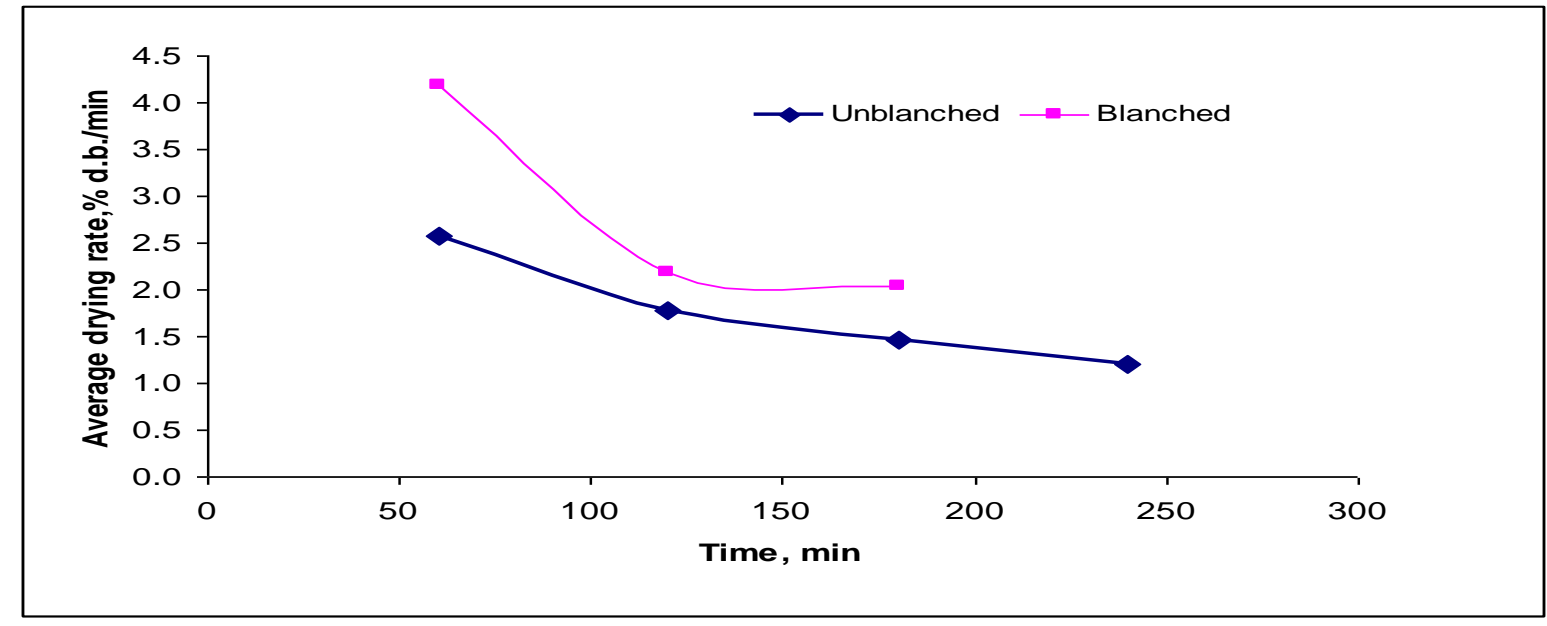

Fig.4 Gas chromatograph of fresh basil leaves

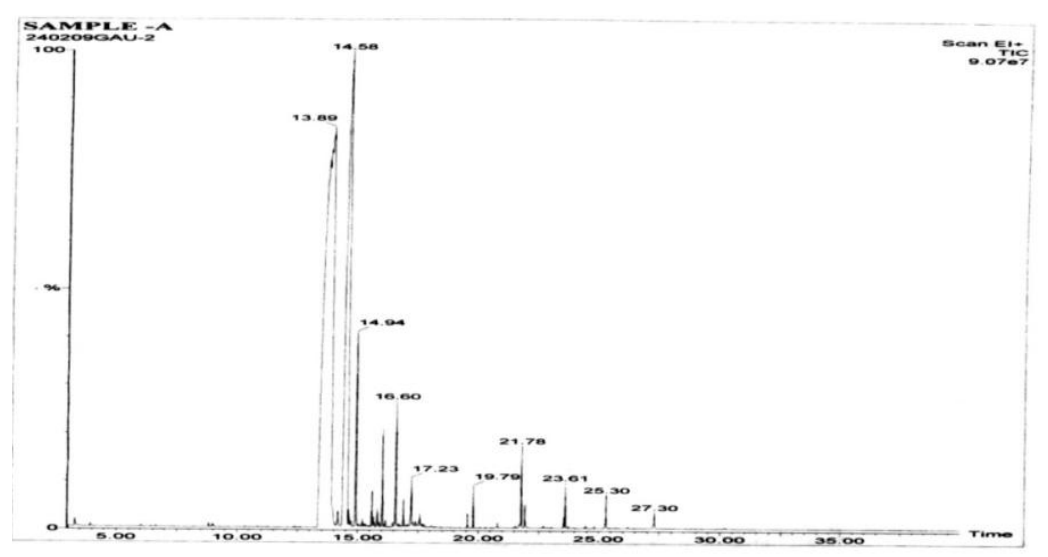

Fig.5 Eugenol and caryophyllene content of solar dried basil leaves at different temperatures: (A) $45^{\circ} \mathrm{C}$; (B) $55^{\circ} \mathrm{C}$ and (C) $65^{\circ} \mathrm{C}$
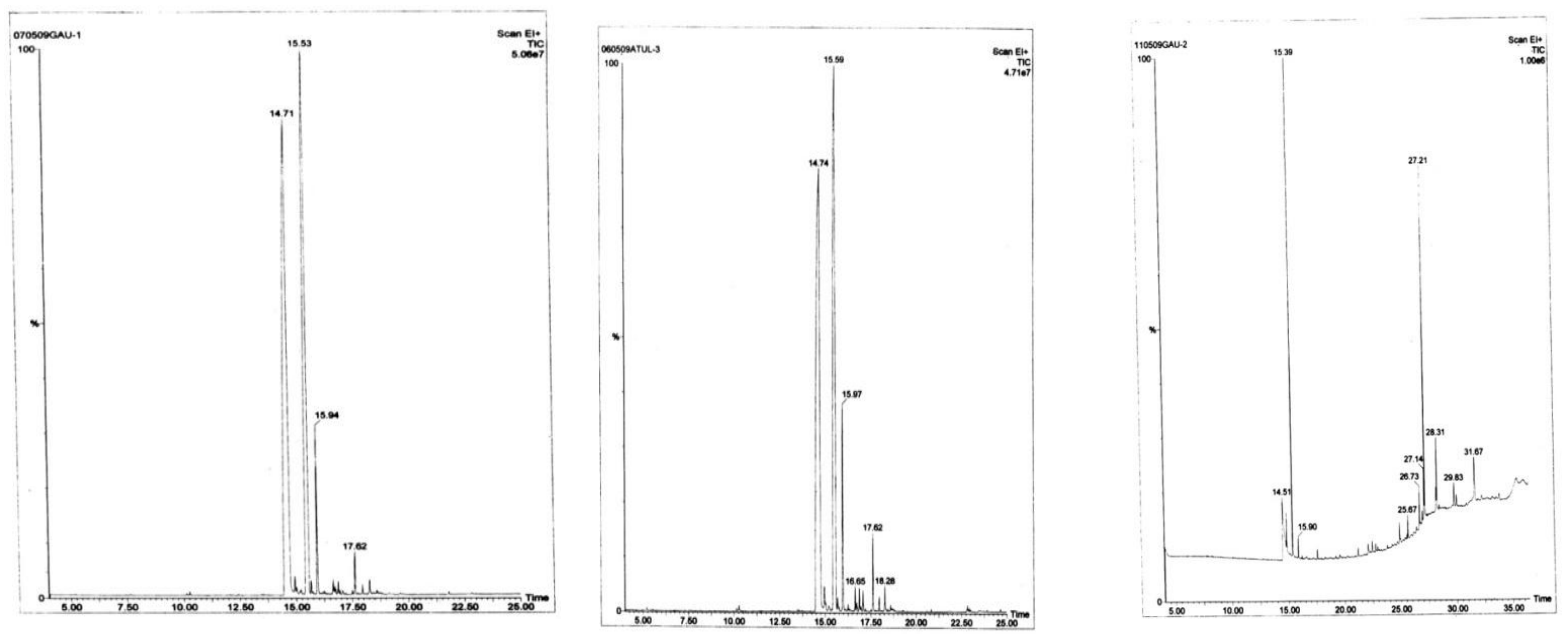
Table.1 Experimental data on volatile oil content on dried basil leaves

\begin{tabular}{|l|l|l|l|l|}
$\begin{array}{l}\text { Type } \\
\text { dryer }\end{array}$ & $\begin{array}{l}\text { Temperature } \\
\left({ }^{\circ} \mathbf{C}\right)\end{array}$ & $\begin{array}{l}\text { Treatment } \\
\text { Unblanched } \\
\text { (UB) } \\
\text { blanched (B) }\end{array}$ & $\begin{array}{l}\text { Volatile oil } \\
(\mathbf{m l} / \mathbf{1 0 0} \\
\mathbf{d . m} .)\end{array}$ & $\begin{array}{l}\text { Loss in Volatile oil } \\
\mathbf{( \% )}\end{array}$ \\
\hline Solar dryer & 45 & UB & 0.76 & 44.12 \\
& 55 & B & 0.73 & 46.33 \\
\hline & 65 & UB & 0.58 & 57.36 \\
\hline & 65 & 0.53 & 61.09 \\
\hline & UB & 0.50 & 63.24 \\
\hline
\end{tabular}

Table.2 Active ingredients available in fresh basil leaves

\begin{tabular}{|l|l|l|}
\hline Peak & Compound & Area $(\%)$ \\
\hline 1 & Eugenol & 61.69 \\
\hline 2 & Caryophyllene & 28.77 \\
\hline
\end{tabular}

Table.3 Eugenol content in the dried basil leaves

\begin{tabular}{|l|l|l|l|l|}
$\begin{array}{l}\text { Type of } \\
\text { dryer }\end{array}$ & $\begin{array}{l}\text { Temperature } \\
\left({ }^{\circ} \mathbf{C}\right)\end{array}$ & $\begin{array}{l}\text { Treatment } \\
\text { Blanched (B) }\end{array}$ & $\begin{array}{l}\text { Eugenol Content in } \\
\text { fresh leaves (\%) }\end{array}$ & $\begin{array}{l}\text { Eugenol content in } \\
\text { dried leaves (\%) }\end{array}$ \\
\hline Solar dryer & 45 & B & 61.69 & 55.23 \\
\hline & 55 & B & 61.69 & 51.61 \\
\hline & 65 & B & 61.69 & 16.39 \\
\hline
\end{tabular}

Table.4 Caryophyllene content in the dried basil leaves

\begin{tabular}{|r|l|l|l|l|}
\hline Type of dryer & $\begin{array}{l}\text { Temperature } \\
\left({ }^{\circ} \mathbf{C}\right)\end{array}$ & $\begin{array}{l}\text { Treatment } \\
\text { Blanched }(\mathbf{B})\end{array}$ & $\begin{array}{l}\text { Caryophyll } \\
\text { Content in fresh } \\
\text { leaves }(\mathbf{\%})\end{array}$ & $\begin{array}{l}\text { Caryophyll } \\
\text { content in dried } \\
\text { leaves (\%) }\end{array}$ \\
\hline Solar dryer & 45 & B & 28.77 & 39.51 \\
& 55 & B & 28.77 & 39.86 \\
\hline & 65 & B & 28.77 & 28.89 \\
\hline
\end{tabular}

Effect of drying conditions on active ingredients

Blanching resulted into the good colour. Hence, blanched samples were taken for further GC-MS analysis to identify the volatile compounds in the fresh basil leaves and as well as in blanched basil leaves dried at the temperature 45,55 and $65{ }^{\circ} \mathrm{C}$ in the solar dryer. Figure 4 shows a typical chromatogram obtained from a fresh sample from GC-MS analysis and Table 2 shows the percentage composition of the identified compounds as calculated from the respective chromatographic areas.

There are, mainly eugenol (61.69 \%) and in minor proportion caryophyllene (28.77\%) 
remaining peaks correspondence to compounds that were not identified.

The two major volatile compounds in fresh basil leaves samples were eugenol and caryophyllene usually considered responsible for the typical basil aroma as per figure 4 . Similar results were reported by (Anon., 1966). The area under the chromatographic peaks of the other compounds is small.

\section{Effect of drying conditions on eugenol compound}

Table 3 shows the eugenol percentage in the dried blanched basil leaves in solar drying at 45,55 and $65{ }^{\circ} \mathrm{C}$ temperature.

In the fresh basil leaves eugenol was $61.69 \%$ and Caryophyllene was $28.77 \%$.

As shown in figure 5, whereas in the solar drying of blanched basil leaves, the eugenol was observed $55.23 \%$ at $45{ }^{\circ} \mathrm{C}$ temperature, $51.61 \%$ at $55{ }^{\circ} \mathrm{C}$ temperature and $16.39 \%$ at $65{ }^{\circ} \mathrm{C}$ temperature which indicates that as temperature increases, the eugenol was decreases

\section{Effect of drying conditions on caryophyllene compound}

The percentage retentions of the second major volatile compound i.e., caryophyllene in the blanched basil leaves was less in lower temperature than the higher temperature in solar drying are reported in Table 4. It shows that as compared to caryophyllene in the fresh sample of basil leaves it increased in basil leaves dried in a 45 to $55^{\circ} \mathrm{C}$ the temperature as per figure 5. This trend was observed similar to trend observed by Mondal (2007).

On the basis of experimental results and data analysis the following conclusions are drawn given as under.
Average drying rate increased with increase in temperature and decreased with increase in time

Blanched sample took less time for drying compared to unblanched samples in each dryer at every temperature from 45,55 and 65 ${ }^{\circ} \mathrm{C}$ temperature.

Volatile oil was found slightly less in the blanched samples in comparison to unblanched samples of basil leaves.

Volatile oil was higher at lower temperature and decreased at higher temperature.

Eugenol was found as major active ingredient in the fresh sample of basil leaves, while caryophyllene was the second major active ingredient.

In the dried basil leaves, the caryophyllene increased, while eugenol decreased most at higher temperatures.

\section{References}

Abdollah, G. P., E. Mahdad, and L. Craker. 2014. Effects of drying methods on qualitative and quantitative properties of essential oil of two basil landraces. Food Chemistry, 141(3): 2440-2449.

Anonymous (1966). Raw materials (N-Pe). In "Wealth of India; Volume-VII"; Publication and Information Directorate, CSIR, New Delhi, India, p.87.

Brophy, J. J., R. J. Goldsack, and J. R. Clarkson. 1993. The essential oil of Ocimum lenuilflorum L. (Lamiaceae) rowing in Northern Australia. Journal of Essential Oil Research, 5(4): 459.

Di Cesare, L. F., D. Viscardi, and R. C. Nani. 2002. Influence of blanching with MW and drying with air-dried on the volatile 
composition of basil. Industrie Alimentari, 41: 25-28.

Di Cesare, L. F., E. Forni, D. Viscardi, and R. C. Nani. 2003. Changes in the chemical composition of basil caused by different drying procedures. Industrie Alimentari, 51: 3575-3581.

Di Cesare, L. F., M. Riva, and A. Schiraldi. 1994. Microwave extraction of basil aroma compounds. In Food Flavors: generation, analysis, and process influence. Proceedings of the 8th International Flavor Conference, 857868. Charalambous, Cos-Greece.

Di Cesare, L.F., D. Viscardi, E. L. Fusari, and R. C. Nani. 2001. Study of the volatile fraction in basil and sage stored at $20^{\circ} \mathrm{C}$. Industrie Alimentari, 40: 12211225.

Di Cesare, L.F., R. C. Nani, D. Viscardi, A. Brambilla, G. Bertolo, and E. L. Fusari. 2000. Drying of the medicinal herbs: evaluation of thevolatile composition. Rivista Italiana 29: 29-37.

Diaz-Maroto, M. C., M. S. Pérez-Coello, and M. D. Cabezudo. 2002. Effect of drying method on the volatilities in bay leaf (Laurus nobilis L.). Journal of Agricultural Food Chemistry, 50: 45204524.

Diaz-Maroto, M. C., M. S. Pérez-Coello, M. A. González Viñas, and M. D. Cabezudo. 2003. Influence of drying on the flavor quality of spearmint (Mentha spicata L.). Journal of Agricultural Food Chemistry, 51: 1265-1269.
Fleisher, A. 1981. Essential oils from two varieties of Ocimum basilicum L. grown in Israel. Journal of the Science of Food and Agriculture, 32(11): 1119-1122.

Mondal S., Mahapatra, S. C. and Mirdha, B. R. (2007). Antimicrobial activities of essential oils obtained from fresh and dried leaves of Ocimum sanctum (L) against enteric bacteria and yeast.www.actahorta.org

Nykanen, I. 1989. The effect of cultivation conditions on the composition of basil oil. Flavour and Frangrance J., 4(3): 125-128.

Nykänen, L., and I. Nykänen. 1987. The effect of drying on the composition of the essential oil of some Labiatae herbs cultivated in Finland. In Martens, M., Dalen, G.A. and Russwurm, H. (Eds.). Flavour Science and Technology, 8388. New York: John Wiley.

Yousif, A. N., C. H. Scaman, T. D. Durance, and B. Girard. 1999. Flavor volatiles and physical properties of vacuummicrowave and air dried sweet basil (Ocimum basilicum L.). Journal of Agricultural Food Chemistry, 47(11): 4777-4781.

Yuparat, P., S. Phoungchandang, and L. K. William. 2014. The effects of predrying treatments and different drying methods on phytochemical compound retention and drying characteristics of Moringa leaves (Moringa oleifera Lam.). Drying Technology, 32(16):1970 1985.

\section{How to cite this article:}

Parmar, M.R., V.B. Bhalodiya and Rajput, R.L. 2018. Retention of Active Ingredients in Solar Drying. Int.J.Curr.Microbiol.App.Sci. 7(10): 2822-2831. doi: https://doi.org/10.20546/ijcmas.2018.710.328 